DOI: $10.17805 /$ zpu.2016.4.21

\title{
Научное знание, неоплатонизм и свободные искусства в культуре Англии раннего Нового времени*
}

\author{
И. И. ЛИСОВИч \\ (МОСКОВСКИЙ ГУМАНИТАРНЫЙ УНИВЕРСИТЕТ)
}

Статья посвящена влиянию неоплатонистского дискурса на научное знание и свободные искусства Англии и Европы раннего Нового времени. Гуманисты стремились преодолеть влияние схоластики и Аристотеля и обратились к философии Платона. Публикация полного свода сочинений Платона М. Фичино предшествовала началу научной революции и аналитическому интересу к деталям физического мира. Платоновская философия проникает в Англию через переписку М. Фичино и Дж. Колета. Тексты Платона, наряду с аристотелевскими, в середине XVI в. становятся основой английского университетского образования. Платоновская Академия дала европейцам и англичанам идею открытого научно-

* Исследование выполнено в рамках проекта «Виртуальная шекспиросфера: трансформации шекспировского мифа в современной культуре», поддержанного грантом РГНФ (№ 14-03-00552а).

The paper was prepared as part of the project "Virtual Shakespearean Sphere: Transformations of Shakespearean Myth in Modern Culture" supported with a grant from the Russian Foundation for the Humanities (No. 14-03-00552a). 
образовательного пространства, что позволило быстро продвигать новое знание. В Англии появились Грэшем-колледж и Лондонское королевское общество, стали проводиться публичные лекции.

К учению Платона восходит представление о визуальном, которое становится основой наблюдательных наук и аргументом, доказательством в новой философии. Обращение к платоновскому пониманию геометрии, гармонии и человека позволило дать статус свободных искусств живописи и анатомии, которые ранее относились к «техне», ремеслам, требующим физического труда. Идеи Платона, неоплатоников и представителей новой философии можно обнаружить в поэтических произведениях Ф. Сидни, К. Марло, У. Шекспира, Б. Джонсона и др. В анатомических теориях А. Везалия и У. Харви, наблюдательной астрономии Т. Браге, И. Кеплера, Г. Галилея и теоретико-методологических построениях Дж. Бруно, Ф. Бэкона, Р. Декарта и И. Ньютона использовались платоновские представления о гармонии, пропорции и мере. Это позволило точно описывать и измерять наблюдаемые объекты.

Ключевые слова: культура Англии; раннее Новое время; научное знание; Платон; неоплатонизм; Аристотель; видимое; доказательство; свободные искусства; новая философия

\section{ВВЕАЕНИЕ}

$\mathrm{H}$ аучная революция в Англии развивалась в общеевропейском культурном контексте, поскольку интеллектуальное коммуникативное пространство, унаследованное от Средневековья, несмотря на Реформацию, оставалось общим. Если в XVI в., во время правления династии Тюдоров, Англия преимущественно была реципиентом европейских научных идей (что отразилось не только в собственно научных практиках, но и риторических, поэтических, живописных и т. п.), то в XVII в. благодаря деятельности ученых Грэшем-колледжа и Аондонского королевского общества английская наука заняла полноправное положение в европейской культуре, а в начале XVIII в. уже претендовала на доминирующее положение.

На историю развития науки оказали влияние социальные факторы: формирование в правление Елизаветы I так называемой новой аристократии, усиление вертикальной социальной мобильности, что привело к проницаемости сословных границ, этот процесс был продолжен во время Гражданской войны XVII в. Немаловажную роль сыграли и историко-политические факторы: в правление Генриха VIII в Англию проникает гуманистическая традиция и интерес к наследию Античности, король поощряет развитие медицины, благодаря чему в Англии становятся известными труды Везалия. В правление Елизаветы I стремление англичан к изучению новых идей получает развитие, интеллектуалы знакомятся с идеями Николая Коперника, Тихо Браге, применяют метод анатомирования практики Андреаса Везалия, основывают публичные лекции и Грэшем-колледж для горожан. В университетских программах благодаря статутам королевы наряду с текстами Аристотеля появляются и платоновские. Новые идеи и открытия, проблема календарной реформы попадают в поле зрения придворных, образованных джентри, поэтов, художников и обычных горожан. Научная революция сопровождала становление Англии и Британии как национального государства и заложила основы будущей империи благодаря деятельности Грэшем-колледжа, одним из направлений которого было развитие навигации (см. подробнее: John Dee ..., 2006).

\section{РАСПРОСТРАНЕНИЕ ИАЕЙ ПААТОНА В АНГАИИ РАННЕГО НОВОГО ВРЕМЕНИ}

Неоплатонизм в раннее Новое время в Европе и Англии становится дискурсивным полем, влияние которого распространяется на научные, художественные тексты 
и практики, что приводит к разрушению между ними когнитивных и дискурсивных границ, установленных схоластами. В Англии раннего Нового времени доверие к новому знанию формируется через идеи Платона и неоплатоников, которые в свободных искусствах становятся аргументом против схоластики и перипатетики. Благодаря этому ученые изменили когнитивный статус таких способностей души, как зрение, воображение и память, что позволило признать в качестве доказательства конструируемый опыт и наблюдение. Научные институции создали особые технологии производства, валидности, трансляции и сохранения знания, полученного экспериментальным путем. Благодаря продвижению неоплатониками математики и геометрии, как выразителей мира идей, в свободных искусствах особое значение придается точности отображаемого мира вещей, это стремление к аутентичности и аналитичности воспроизведения проникает в английскую культуру.

Платоновская Академия с ее дискурсом свободного обмена мнениями, в котором принимали участие философы, их ученики, афиняне, политики, медики, поэты и другие жители Афин, стала примером для создания открытых научно-образовательных коммуникативных пространств, где обсуждалось знание нового типа, благодаря чему оно проникает в культурные практики. Марсилио Фичино и его покровителю Козимо Медичи 1 принадлежит идея возрождения платоновской Академии как альтернативной средневековым университетам диалогической коммуникативной площадки, где горожане, ученые, философы, теологи и художники могли бы обмениваться идеями. О. Б. Аубова отмечает, что «первые академические сообщества отличались от университетов с их обязательной наукой свободой занятий, а от цехов - опять-таки свободным интересом ко всем теоретическим и практическим тонкостям воссоздания реальности. Это было свободное сообщество для образования и самообразования, такая инерция сохранилась надолго...» (Аубова, 2009: 24).

В Англии такими площадками стали публичные лекции по медицине, Грэшем-колледж и Аондонское королевское общество и т. А. Гуманист стал одной из центральных фигур общеевропейского коммуникативного пространства, которое ученые впоследствии назвали «Respublica litteraria», а Роберт Бойль - «Невидимым колледжем». Это пространство объединяло европейских интеллектуалов, принадлежавших и не принадлежавших разным институциям, размывало выстраиваемые границы наций и игнорировало религиозные разногласия в период Контрреформации и Тридцатилетней войны.

Научные идеи и практики через открытые коммуникативные стратегии, с одной стороны, оказывали влияние на формирующуюся культуру общества модернити, с другой - сложившиеся и развивающиеся философские идеи, художественные практики влияли на репрезентацию научных достижений, открытий, опытов и текстов. Формирование и развитие научного дискурса испытало на себе влияние процесса формирования национального английского языка, который интенсивно развивался под воздействием переводов Библии и развитием риторики, поэзии, драматургии, прозы и науки. Но эти процессы обмена возможны при условии, если научный метод был открыт и понятен на обыденном уровне восприятия, и здесь основную функцию выполнило утверждение зрения и измерения как способа исследования и доказательства. В Англии формирование знания нового типа разворачивалось, в том числе, и в спорах неоплатоников со схоластами-аристотеликами, которые в правление Елизаветы I в основном концентрировались в Оксфорде и Кембридже. Тогда как в работах Аж. Аи, Аж. Бруно, У. Гилберта, У. Харви (У. Гарвей), Г. Бриггса видно влияние 
Платона, соединенного с герметической традицией благодаря работам М. Фичино. А. Койре полагал, что началом научной революции стало методологическое противостояние платоников и аристотеликов, которое привело к утверждению математики как критерия истины и изменению астрофизической картины мира в целом (Койpe, 1985).

В Англии раннего Нового времени в области свободных искусств формируется устойчивая неоплатоническая традиция, что подтверждают исследования. М. Фичино, переводчик полного свода сочинений Платона на латинский язык, вел обширную переписку с гуманистами, учеными и правителями, копируя по их заказу переведенные и написанные им самим тексты, что позволило их быстро распространить (см. подробнее: Кудрявцев, 2008: 161-222, 262-286).

Одним из адресатов был приближенный Генриха VIII гуманист Ажон Колет, который, по мнению С. Р. Ажейн, был знаком с работами и переводами М. Фичино и принес идеи неоплатонизма в Англию (Jayne, 1963: 295). $\Lambda$. В. Софронова уделяет особое внимание переписке и полемике Колета и Фичино в монографии «Ажон Колет: опыт реставрации образа христианского мыслителя ренессансной эпохи» (Софронова, 2009: 156-206) и статье (Софронова, 2006). Она устанавливает связь между «христианским гуманизмом» Колета и неоплатонизмом Фичино, которые обсуждали вопрос о том, какая способность души является наиважнейшей для познания (воля, интеллект или любовь). Фичино в трактате «Платоновское богословие о бессмертии души» (опубл. 1482) обосновывает «во всем созвучие платоновских мыслей с Божественным законом» (Фичино, 1996: 169), стремится возродить истинную религию, встраивая корпус платоновских сочинений в культурное пространство христианской Европы (см. подробнее: Акопян, 2014а). Связь христианства и неоплатонизма закрепилась в культуре Англии раннего Нового времени, и, хотя Колет не воспринял герметический и алхимический аспекты учения Фичино, они тоже проникли в английскую культуру.

С. Р. Ажейн прослеживает историю публикаций сочинений Платона и их рецепцию в Англии от времени ранних Тюдоров до эпохи Стюартов и полагает, что влияние неоплатонизма на английскую культуру середины XV-XVI вв. историками науки было преувеличено, поскольку за это время Платон был издан в Англии два раза, и большинство существующих аллюзий отсылают не к Фичино и Платону, а к их французским и итальянским интерпретаторам. Основными носителями неоплатонических оказываются ученые нового типа и поэты, особенно Ф. Сидни, У. Шекспир и др. Расцвет неоплатонизма происходит во время правления Елизаветы I, которая признавала первенство Платона среди философов (Jayne, 1995).

Согласно изданному Елизаветой I Статуту Кембриджского университета 1559 г. (возвращенный статут Эдуарда VI 1549 г.) в третьей главе прописывается содержание лекций по философии, которые лектор должен публично читать по Аристотелю ( Проблемы», «Большая этика» и «Политика»), Плинию Старшему или Платону для магистров Оксфорда (в 1565 г.) и Кембриджа (в 1570 г.). Философию разделили на метафизическую, натуральную и моральную. Профессор математики читал космографию по П. Мела, Плинию Старшему, Страбону или Платону; арифметику - по Аж. Кардано, геометрию - по Эвкдиду, астрономию - по К. Птолемею (Order of Queen Elizabeth ..., 1853: 146). Студентам предписывалось посещать лекции в обязательном порядке. Платон попадает в обязательное университетское образование уже в правление Эдуарда III. Благодаря этому влияние неоплатонизма синхронно и довольно быстро распространялось на разные сферы культуры и дискурсы от философ- 
ского, собственно научного до поэтического, и эта уникальная проницаемость дискурсивных границ дала специфический культурный синтез.

Э. Кассирер подробно описывает Кембриджских платоников, связывая их с Платоновской академией Фичино (Cassirer, 1953). Выделяя среди создаваемых человеком «символических форм» язык, миф, религию, искусство и науку, объединенных культурой, он рассматривает их как самостоятельные образования, не сводимые друг к другу. Исходя из әтого, можно сделать предположение, что именно благодаря платонизму искусство и «новая философия» ненадолго совпали во время ее рождения, в том числе и в феномене Кембриджских платоников, враждебно настроенных по отношению к Ф. Бэкону и его последователям.

Влиянию Платона на Н. Кузанского, М. Фичино, Э. Герберта, Я. А. Коменского, Р. Фладда, Кембриджских неоплатоников, Р. Кедворта, Р. Аекарта, Аж. Аокка, Г. В. Аейбница, Э. Э. Купера, 3-го графа Шефтсбери и на основные концепты раннего Нового времени посвящен ряд работ (см., например: The Platonic tradition ... , 2002; Klibansky, 1939), в том числе и коллективная монография «Платонизм у истоков современности: исследования платонизма и ранней современной философии» под редакцией А. Хедли и С. Хаттон (Platonism at the origins ... , 2008).

\section{НЕОПААТОНИЗМ, МАТЕМАТИКА И МЕТОАОАОГИЯ НОВОГО ЗНАНИЯ}

В истории науки общим местом является утверждение, что научная революция произошла благодаря замене схоластической аристотелианской дедуктивной парадигмы на индуктивную, основанную на наблюдении и эксперименте. Публичная демонстрация опытов и наблюдаемых тел и сделала знание доступным для понимания. Обычно не вызывает сомнений представление, что процесс методологической переориентации был запущен открытием европейцами Нового Света, изобретением печатного станка и гуманистическим антропоцентризмом, изменившим статус познающего субъекта ${ }^{2}$. Влияние христианства и неоплатонизма, витализма и мистических практик на ученых обычно рассматривается как некий пережиток, который впоследствии был преодолен в новой парадигме (Койре, 1985; Аосев, 1998). Но возник некий методологический парадокс из-за представления, которое распространено в учебниках для вузов по логике, истории науки и т. п., что дедуктивный метод восходит к Платону, а индуктивный — к «Физике» Аристотеля и программе восстановления наук Ф. Бэкона.

Физические представления Аристотеля были связаны с метафизическими на основе дедуктивной логики, обосновывавшей геоцентрическую модель закрытого космоса. Именно поэтому они противоречили, с одной стороны, коперниканской математической гелиоцентрической модели, построенной на точных астрономических данных и математическом расчете; с другой - экспериментальной индукции на основе физики движения И. Кеплера, Г. Галилея, теории магнетизма У. Гилберта, теории кровообращения У. Харви. Но в работах ученых раннего Нового времени отсутствует чистая индукция, поскольку даже физические экспериментальные данные вписываются, например, в платоновскую идею о математической гармонии космоса и четырех стихиях.

В этой связи Р. Рорти писал, что «сверхъестественный мир для интеллектуалов XVI века моделировался платоновским миром Идей, точно так же, как наш контакт с ним моделировался его метафорой видения. Мало кто верит сегодня в Платонистские Идеи, не верят даже те, кто различает чувственную и разумную души. Но образ Зеркальной Сущности остался с нами... <...>. Все еще чувствуется, что эта природа 
проявляет свой отличительный характер наиболее отчетливо через определенный вид познания - познание высочайших и чистейших вещей: через математику, саму философию, теоретическую физику и все, что связано с универсалиями» (Рорти, 1997: 33 ).

Аристотелики были непримиримыми оппонентами Галилея и ученых, обосновывавших свои открытия на заключениях, полученных экспериментально-наблюдательным путем: то, что являлось фактом для одних, не признавалось в качестве такового их оппонентами (см. подробнее: Clark, 2007). Прежде чем апеллировать к опььту как аргументу в споре, необходимо было признать достоверность зрения, при помоши которого и регистрируется объект или эксперимент. В схоластической системе глаз познающего субъекта не пользовался необходимым кредитом доверия. Признавали твердо установленным только то «видимое», которое встраивалось в существующую систему, что и требовал дедуктивизм. Именно зрение и связанные с ним искажения были предметом критики схоластов, для которых последним доказательством было логически непротиворечивое высказывание, тогда как для ученых нового типа аргументом было наблюдение и эксперимент, которые можно было воспроизвести в известных условиях и зафиксировать с помощью измеряемых параметров. Культура так же реагировала на эту полемику и рефлексировала по поводу иллюзорности видимого мира, что проявилось в творчестве У. Шекспира (см. подробнее: Chen-Morris, 2013), Аж. Аонна и барочной игре визуальными обманами (Gilman, 1978; Castillo, 2010). B споре с перипатетиками ученые были вынуждены вырабатывать строгие критерии оценки достоверности наблюдения, поставленных опытов, фиксации данных, измерительных технологий и инструментов, подчиняя их математическому выражению.

Но для перипатетиков экспериментальная физика и математика не были связаны в единую цепь аргументации и не имели статуса окончательного доказательства. Тогда как ученые Нового времени выстроили принципиально иную модель исследования: зрение как когнитивная способность, тщательная дескрипция видимого объекта, определение его физических свойств и параметров, математическое обобщение явления / закона. А логические рассуждения и построения стали вспомогательным инструментом репрезентации наблюдаемого явления. В этой связи А. Койре отмечает следующее: «...речь шла о выборе между физикой Аристотеля, представлявшейся более простой, и другой физикой, казавшейся более сложной; о выборе между доверием к чувственному представлению (последовательным проводником этой точки зрения был Бэкон) и отказом от такого доверия в пользу чистого теоретизирования и т. А.» (Койре, 1985: 12). Что же послужило той точкой разлома, которая позволила признать чувственное восприятие человека в качестве доказательства? Таким весомым авторитетом для гуманистов и ученых раннего Нового времени, способным противостоять Аристотелю по всем позициям, стал его учитель - Платон. Койре отмечает, что именно платоновская модель вселенной лежала в основе коперниканского поворота $^{3}$. Но, дополняя Койре, можно утверждать, что влияние идей Платона отразилось не только на астрономии и физике, но и живописи, анатомии, поэзии, теологии, герметике, политике, и началось гораздо раньше.

Одним из первых теологов раннего Нового времени, которые инкорпорировали математику в христианскую доктрину, был кардинал Николай Кузанский, инициировавший обсуждение календарной реформы. Он апеллирует как к античным, так и церковным авторитетам, говорившим о связи числа и познания истины ${ }^{4}$. Примечателен также факт, что перевод на латинский, комментирование и публикация полного сво- 
да сочинений Платона в 1463-1468 гг. гуманистом М. Фичино предшествовали началу научной революции и аналитическому интересу к деталям физического мира (см. подробнее об истории перевода Платона в Европе: Акопян, 2014а). Это было визуально выражено, например, в акварелях Альбрехта Аюрера (1471-1528; «Кусок дерна», «Водосбор» и «Заяц»); в звездной и географической картах, которые художник создал в сотрудничестве с учеными Иоганном Стабием и Конрадом Хейнфогелем ${ }^{5}$ в астрономических, медицинских и ботанических атласах, географических картах, которые во множестве появляются в Англии и Европе XVI-XVII вв.

Гуманисты раннего Нового времени воспринимали себя продолжателями утраченного или искаженного древнего знания, поэтому их научная деятельность и, соответственно, научная революция началась с точного перевода на латинский язык и комментирования Платона, Прокла, Плотина, Порфирия, Аионисия Ареопагита, Птолемея, Галена, Аристотеля ( Поэтика»), Аукреция и др. Проект, который начинался как «studia humanitatis» и предполагал владение древними языками, постепенно включил в себя не только идею совершенствования образования, себя, общества, города, государства, но и реформации религии и знания в области анатомии, географии, астрономии, математики и физики. Масштабность этого проекта реформации и возрождения отчасти была связана с универсальностью существующей образовательной модели и разносторонностью интересов гуманистов, одинаково увлекавшихся риторикой, астрономией, собиранием древностей, составлением гербариев, анатомированием.

\section{УЧЕНЫЙ (МАГ / ВИРТУОЗ / АРТИСТ /ГЕНИЙ) В ПОИСКАХ ГАРМОНИИ ВСЕАЕННОЙ}

Тем не менее современные исследования неоплатонизма эпохи Ренессанса, как правило, смещают акцент в сторону герметической и мистической доктрины о душе и познании, что в полной мере отразилось в эротико-мистической метафорикеб трактатов гуманистов (см., например: Йейтс, 2000: 24-78), художественных текстов, живописи и скульптуры XV-XVII вв. Конечно, эта составляющая была напрямую связана с платоновской идеей «познания как восхождения», но не исчерпывалась ею и, скорее, была составной частью чувственного познания мира, сотворенного Богом, как отправной точки для восхождения. М. Фуко описал корреляцию в мистике Ренессанса между чувственно воспринимаемой природой / вещью и символом / текстом как интерпретацией ${ }^{7}$.

Но для ренессансного мага / виртуоза было недостаточно интерпретации, он стремился к личному взаимодействию с Природой / вещью, символом / текстом. М. Фичино продолжил в этом направлении эзотерическую традицию и находился у истоков натуральной магии 8 . В трактате «О стяжании жизни с небес» (1489) Фичино вслед за Платоном устанавливает корреляцию между звездами и земными телами посредством аналогии образов и форм, предполагая, что можно прочитывать знаки судьбы на звездном небе и влиять на нее посредством магических талисманов, поскольку эти миры связаны жизненным началом души (см. об астрологических представлениях гуманистов: Акопян, 2014b). Но неоплатонические эзотерические учения и практики отличались от общедоступных научных и образовательных проектов раннего Нового времени тем, что хранили закрытость знания через зашифрованность текстов и предполагали его прямую передачу от учителя к ученику.

Гуманисты возродили платоновскую идею человека как медиатора между подлунным и надлунным миром, божественным и телесным, душе которого через образ 
доступно познание Вселенной 9 . Аанный концепт гения будет востребован в XVIII в. при восприятии жизни и открытий сэра И. Ньютона (см. подробнее: Аисович, 2015: 254-279). Это представление о специфике человеческого познания станет основой для признания достоверности чувственного опыта, а воображение как способность души будет моделировать целостную реальность для исследователя, отправляющегося в интеллектуальное путешествие. Основным чувственным инструментом познания становится наблюдение и зрение ${ }^{10}$.

Идеи Платона, инкорпорированные в учения гуманистов, были продолжены в наблюдательной астрономии, в представлениях о человеческом теле А. Аюрера и А. Beзалия, космологии Н. Кузанского, Аж. Бруно, У. Гилберта, кембриджских платоников и др. Влияние математических идей Платона и Пифагора на эстетическую составляющую Нового времени отметил А. Ф. Аосев, особо выделивший «физико-математический тип возрожденческой культуры» (Иосев, 1998: 105)11. Он отделяет «индивидуалистическое», «романтическое», «артистическое» проявления гуманизма от «рационального», «механистического», создавая оппозицию-анахронизм. Это восприятие неоплатонизма в отчетливой форме проявится позднее в творчестве английского романтика У. Блейка, объявившего войну безупречному И. Ньютону, которого он изобразил с идеальным античным телом, в лавровом венке и с циркулем. Аосев стремится показать эволюцию от математизации к творческому артистизму у Аюрера, $\Lambda$ еонардо да Винчи и др., оговаривая пифагорейство и неоплатонизм у Кеплера и Галилея как нечто архаичное, от которого наука Нового времени стремится избавиться.

Э. Панофски также указывает на основание в учении Платона, способное объединить познание истины (философию), науку и искусства: «...ценность творения художника, как и научного исследования, определяется для Платона тем, в какой степени в них содержится теоретический, особенно математический, элемент...» (Панофски, 2002: 17). Тем не менее между дихотомиями А. Ф. Аосева, описывающего эволюцию художников («артистов») Ренессанса, нет жесткого противопоставления. Философ несколько насильственно категориально разделил эти явления, которые мирно сосуществовали в работах гуманистов и культурных практиках, что соответствовало идеям платонизма.

Так, перевод М. Фичино корпуса Гермеса Трисмегиста оказал сильное влияние на гуманистические представления о человеке-маге, человеке-творце, человеке-артисте, воплощением которого в Англии стали Ажон Аи, Иниго Ажонс, доктор Фаустус К. Марло (Захаров, Черноземова, 2013: Электронный ресурс) и шекспировский Ариэль. Фичино, используя платоновский принцип аналогии вечного и рождающегося, интерпретирует отношения тела и души через геометрический образ окружности, считая ее метафизическим центром тела ${ }^{12}$. Ф. Йейтс примером влияния этого перевода считает трактаты Агриппы Неттесгеймского, Ажованни Пико делла Мирандолы, Аоренцо Валла, Роберта Фладда, «О гармонии мира» ( «De harmonia mundi», 1525) Франческо Ажорджо (Азордзи), францисканца из Венеции, где он полно раскрывает тему «универсальной гармонии, гармонических соотношений между человеком, микрокосмом, и большим миром вселенной, макрокосмом. $<\ldots .>$ И хотя число при этом понималось в пифагорейском или качественном, а не в собственно математическом смысле, сама сосредоточенность на числе как ключе к мирозданию была столь сильна, что она прокладывала дорогу подлинно математическому пониманию вселенной» (Йейтс, 2000: 143-144).

О. Гал доказывает, что лежащий в основе понятия гравитации «закон обратных квадратов», который сформулировал И. Кеплер, был связан со стремлением матема- 
тически расшифровать совершенство и гармонию Бога и Вселенной, представление о которых разрушали астрономические открытия XVII в. Ньютоновская математизация природы возникла на фоне сомнений в ее определенности и совершенстве, поскольку ее нельзя было представить посредством математического знания, на которое надеялись платоники. Но И. Ньютон и его последователи восстановили гармонию, открыв простые, совершенные законы, лежащие в основе всех, казалось бы, «непослушных» явлений, окрасивших мироощущение барокко в трагические тона (Gal, 2013).

\section{ВОСПРИЯТИЕ УЧЕНИЯ ПААТОНА И АРИСТОТЕАЯ УЧЕНЫМИ РАННЕГО НОВОГО ВРЕМЕНИ}

Философия Платона в раннее Новое время стала основой для обоснования видимо воспринимаемого мира как объекта познания, способного открыть путь к Истине. Тексты Платона часто носят профетически произвольный характер, в них он играет, мифологизирует ${ }^{13}$, рассказывает и рассуждает, что отличает его от жестко выстроенных структурированных текстов Аристотеля и перипатетиков. Эта платоновская особенность изложения давала возможность интерпретировать, продолжить его мысли и позволяла предположить множественные решения и пути познания, что делали М. Фичино, Г. Галилей, Ф. Бэкон и Р. Аекарт. Тогда как высказывания Аристотеля, носившие однозначно логически выстроенную и законченную форму, приводили ученых в основном к ссылке на его авторитет как последний аргумент, закрывая возможность для интеллектуального путешествия в готовом, закрытом, завершенном и предсказуемом аристотелианском космосе, куда требовалось только встроить то или иное явление.

Аристотель продолжил идеи Платона, но предложил только один вектор пути к Истине, сохранив и усложнив иерархичность структуры. На принципиально открытое платоновское высказывание, предполагающее вариативность его интерпретации, он наложил технику формальной логики, благодаря чему минимизировал непредсказуемость вывода и количество путей, приводящих к нему. Поскольку Аристотель стремился упорядочить и довести до логического завершения гносеологические проблемы, поставленные Платоном, то гуманистам не составило особого труда инверсировать этот вектор: оттолкнувшись от Аристотеля, они смогли подняться обратно к Платону и вернуть урезанные учеником иные направления познания.

Причем во многих научных текстах XVI-XVII вв., где критикуется позиция Аристотеля, в качестве оппонирующей возникает точка зрения Платона, что видно на примере Аж. Пико делла Мирандолы (Schmitt, 1967) и «французского Платона» П. Рамуса (1515-1572), выдвинувшего тезис: «Что бы ни сказал Аристотель, ложно» (Матвиевская, 1981: 36) ${ }^{14}$. Как полагает Х. Керни, критика Рамусом Аристотеля с позиций неоплатонизма легла в основание Грэшем-колледжа, поскольку Энтони Уоттон, первый профессор теологии этого лондонского учебного заведения, был убежденным сторонником Рамуса и перевел его «Аогику», а Генри Бриггс благодаря увлечению рамизмом пришел к прикладной математике. Эти ученые создали часть образовательного паттерна, направленного на практику и прикладную математику, в отличие от грамматических школ (Захаров, Гайдин, 2006) и старых университетов (Kearney, 1970: 65).

Какие же идеи Платона, связанные с обоснованием зрения и измерения как основы познания, легли в основу новых методов наблюдения и эксперимента? Платон 
предлагает возвысить до познания неизменного математические науки, которые замыкаются на своих предметах и обслуживают утилитарные цели купцов, ремесленников, музыкантов, астрономов. Платоновское познание Вселенной как тела - это восхождение от видимого глазом к тому, «что можно видеть не иначе как мысленным взором» (Платон, 2007: 346), и оно предполагает ведущую роль визуального восприятия как вечного, так и возникающего, изменяющегося, которые в своем абсолютно чистом выражении представлены в виде числа, линии, сочетания и пропорции (см. подробнее: Аисович, 2015: 31-38). Математика соединяет чувственное с миром идей.

Начертаемые, идеальные геометрические тела и их пропорции, имеющие математическое выражение, как и связанные между собой ступени познания, ведущие вверх, к Богу, и обратно вниз, соединяют чувственный и идеальный миры через математическую диалектику. Человек созерцает / познает космос по закону подобия через образ по нисходящей: от идеи к первообразу и к возникающему. Познающий человек должен настроить движения своей души относительно совершенным движениям космоса.

В философии Платона выстраиваются основания для чувственного познаниявосхождения к неизменной и вечной Истине через глаз, зрительнье ошушения, душу и мыслимый, запечатленный в ней эйдос к одушевленному космосу и неизменной Идее. Цель познающего субъекта - установить первообраз и высказаться о нем как можно более адекватно, причем основными убедительными качествами, которые позволяют опознать и описать его, выступают красота и пропориия, воспринимаемые глазом, которые нужно сверить с тем, что видимо мысленным взором. И когда эти образы, внешний и внутренний, совпадают, происходит установление Истинь. Основным инструментом и аргументом познания «Книги природы» гуманистами была признана геометрия, точное измерение, опыт и наблюдение над природой, где Творец запечатлел первообразы. Геометрия стала связующим звеном между астрономией, геодезией, физикой и алгеброй.

\section{СВОБОАНЫЕ ИСКУССТВА И НЕОПААТОНИЗМ \\ В НАУЧНЫХ КОНЦЕПЦИЯХ АНГАИИ РАННЕГО НОВОГО ВРЕМЕНИ}

Живопись и анатомия также стремились постичь «Книгу природы», но для әтого было необходимо придать им статус свободных искусств, что произошло благодаря их сближению с геометрией через платоновские понятия меры, пропорции, гармонии и красоты. Это сделали А. Аюрер и А. Везалий, заложив основу для анатомических и ботанических атласов, иллюстраций к научным трудам. В них ученые стремились с наибольшей точностью не только воспроизвести детали объекта, но и выразить базовую идею исследования. Аюрер придал высокий статус художнику-мастеру, способному постичь гармонию человека и мира. Собранное он сверяет в душе с тем, что видит умом. Это делает его способным подняться до первообраза и творить, не прибегая каждый раз к запечатленному в природе. Везалий исходил из платоновского представления о человеке как воплощенной Богом гармонии между человеческим телом, душой и миром. Он также оправдал необходимость точных иллюстраций, ссылаясь на геометрию. Глаз для Везалия - инструмент познания, зрение - инструмент, которым пользуется искусство анатомии.

В физике и астрономии Аж. Бруно и У. Гилберт обращаются к Макрокосму. Бруно в работах, которые он написал и опубликовал во время своего пребывания в Англии, отдает предпочтение математике Пифагора перед геометрией Платона. Математика 
очищена от воображения и сохраняет принцип аналогии между макро- и микромирами, поэтому больше подходит для познания-восхождения. Она позволяет человеку освободить интеллект от отягощающего тела, чтобы он, вернувшись назад, преобразил тело. Тем не менее способ рассуждения о физической природе движения астрономических тел у Бруно остается аристотелианским.

У. Гилберт установил магнетические законы движения Земли и астрономических объектов, исходя из платоновского представления об одушевленности мира. Через опыты с магнитами, описанные геометрически, и навигационные данные он демонстрирует природу движения небесных тел. Она основана на том, что Земля и другие планеты обладают магнетизмом (формой души), которая сохраняет мировой порядок. Материнское начало Земли - основа разумной гармонии, выраженной в геометрической форме (образе) и числе, заложенных Творцом. Одушевленность Вселенной и Земли Гилберт напрямую связывает с платоновским представлением о живом разумном космосе.

И. Кеплер, знакомый с трудом У. Гилберта «О магните», утверждал, что пропорции, проявляющие себя в геометрических формах природы, обусловлены идеей Творца, который наделил Землю необходимой силой, порождающей эти формы. Ученый приходит к выводу, что в надлунном и подлунном мире, который Аристотель жестко разграничивал, управляют одни и те же законы гармонии. Благодаря этому единству миров Г. Галилей также обосновывает принцип восхождения от опыта и наблюдений к умозаключениям. Он принимает идею Платона о том, что посредством математики человеческий ум способен познать божественную истину. Причем, Галилей воспроизводит платоновскую логику восхождения из тьмы незнания к божественному свету, опираясь на доказанные факты. Он ставит перед учеными задачу направить взгляд на то, что доступно непосредственному наблюдению и не искажает предмет исследования.

Высказанные основоположниками принципов науки Нового времени представления о способностях познающей души и способах познания мира через наблюдение и опыт были продолжены Ф. Бэконом. Он признает наличие принципа, который связывает физические и метафизические формы (идеи), благодаря чему возможно познание законов, универсальных форм и их материального проявления. Бэкон переконструирует эпистемологическую пирамиду: от наблюдения и опыта философ восходит к обобщениям, выявляет действующие принципы, а затем переносит закон на подобные материальные явления, опять перепроверяя его действие экспериментом. Р. Аекарт полагал, что индукция, основанная на данных, полученных при помощи чувственного восприятия, и конструирование объекта при помощи воображения не дают возможность постичь метафизическое, поскольку только в человеческом разуме существует идея Бога и души.

Противостояние картезианцев и бэконианцев определило основные методологические споры со второй половины XVII в. Если Р. Аекарт не признавал математические методы применимыми к физическим явлениям, то И. Ньютон объединил индуктивизм Ф. Бэкона с математическим обоснованием физических явлений. Он чувственно наблюдаемые природные физические явления и эксперимент выразил геометрически-алгебраическим способом и теоретически обобщил это в своих законах. Ньютон следует точке зрения Бэкона, отсекая метафизический план познания, ограничиваясь только теми свойствами вещей, света, астрономических объектов, которые могут быть познаны при помощи человеческих чувств. Из дискурса Ньютона исчезают ви- 
тальные термины, которые свидетельствуют о восприятии Вселенной как одушевленного тела, поскольку ученый останавливается там, где он видит проявления божественной сущности, недоступной опытному познанию и дескрипции с позиций физики и математики.

\section{ЗАКАЮЧЕНИЕ}

Неоплатонизм эпохи Ренессанса, как правило, рассматривают вписанным в контекст мистико-герметической традиции и моральной философии, где Вселенная репрезентирована одушевленным целым, части которой связаны по принципу подобия, например образ социума как тело человека. Но это платоновское представление о мире включало в себя и геометрическую составляющую, основанную на постигаемом зрением и умом образе, что позволило вернуть геометрии, алгебре и наблюдению статус доказательства в поиске истины. Именно перевод корпуса текстов Платона положил начало научной революции раннего Нового времени, а А. Аюрер одним из первых дал теоретическое обоснование необходимости точного измерения и наблюдения за природой, которое доступно художнику и ученому.

Эту тенденцию к обоснованию чувственного, точнее, зрения, как необходимой ступени в познании, можно найти в теоретическом обосновании методов, основанных на наблюдении, в анатомировании А. Везалия и У. Харви, наблюдательной астрономии Т. Браге, И. Кеплера, Г. Галилея и теоретико-методологических построениях Аж. Бруно, Ф. Бэкона, Р. Аекарта и И. Ньютона. Зрение подтверждает факты и является основанием признания в качестве доказательства наблюдаемые явления или опыты. Зрение связывает мир подлунный и надлунный, чья однородность и единство законов были доказаны Н. Коперником, Галилеем и Ньютоном. Причем Бэкон, а за ним Ньютон отсекли в качестве объекта рассуждений и изучения гипотезы и философские спекуляции, не подтверждаемые опытом, оставив, таким образом, вне экспериментального познания, основанного на геометрическом и алгебраическом доказательстве, сущность божественного, исследуя только проявление божественных свойств и законов в физической природе.

\section{ПРИМЕЧАНИЯ}

1 «Наконец, в наше время прославленный муж платонические пиры, назначил главой их Франческо Бандини» (Фичино, 1981: 144).

2 Как отмечает Р. Смит, «книгопечатанье, географические открытия, Реформация в религии и революция в науке были событиями, направленными вовне, 一 коллективными достижениями, которые преобразили общий горизонт культуры. В то же самое время эти события во многом преобразили человеческую веру, вкус и воображение. ...Пауль О. Кристеллер полагал, что нечто новое появилось в человеческом опыте - некая "тенденция [авторов] относиться серьезно к своим собственным чувствам и событиям, мнениям и предпочтениям”. <..> Как и подразумевает само слово “гуманизм”, это было движение, поместившее человека в центр внимания и воспевшее его способность, вдохновленную античными образцами, открывать в себе самом великие качества» (Смит, 2008: 21-22).

3 По мнению А. Койре, «трудность аристотелевской концепции состоит в необходимости “вместить" евклидову геометрию внутрь неевклидовой Вселенной, в метафизически искривленное и физически разнородное пространство. Признаемся, что Аристотель абсолютно не был этим озабочен, ибо геометрия отнюдь не являлась для него фундаментальной наукой о реальном мире, которая выражала сущность и глубинное строение последнего; в его глазах геометрия была лишь некоторой абстрактной наукой, неким вспомогательным средством для физи- 
ки - истинной науки о сущем. Фундамент истинного знания о реальном мире составляет для него восприятие - а не умозрительные математические построения; опыт - а не априорное геометрическое рассуждение. Намного более сложная ситуация предстала между тем перед Платоном, который предпринял попытку сочетать идею Космоса с попыткой сконструировать телесный мир становления, движения и тел, отправляясь от пустоты ( $\chi \omega \rho \alpha)$, или чистого, геометризованного пространства. Выбор между этими двумя концепциями - космического порядка и геометрического пространства - был неизбежен, хотя он и был произведен лишь позднее, в XVII в.» (Койре, 1985: 17-18).

4 «..великие светочи древности приступали к трудным вещам только с помощью математических подобий. <...> Не Пифагор ли, первый философ и по имени и по делам, положил, что всякое исследование истины совершается через число? Пифагору следовали платоники и наши первые учители настолько, что Августин, а за ним Боэций утверждали, что первоначальным прообразом творимых вещей было в душе создателя несомненно число. Разве Аристотель, который, опровергая предшественников, желал предстать единственным в своем роде, сумел показать нам в "Метафизике” различие сущностей каким-то другим образом, чем в сравнении с числами?» (Кузанский, 1979: 65). Начало полемики с Платоном и неоплатониками, а также попытка примирить его учение с христианской доктриной в раннем христианстве анализируется в работе Г. Чадвика (Chadwick, 1984).

5 Стабий сделал набросок карты звездного неба с градусной сеткой. По этим данным Хейнфогель изготовил на плоскости расположение звезд, используя применявшийся еще в то время каталог неподвижных звезд Птолемея; затем Аюрер прорисовал фигуры созвездий. Изображения двух полушарий даны в стереографической проекции с центрами в полюсах эклиптики. Внизу карты содержится надпись на латыни: «Иоганн Стабий направил - Конрад Хейнфогель расположил звезды - Альбрехт Аюрер заполнил круг изображениями». В четырех углах карты Северного полушария изображены древние астрономы: Арат из Сол (слева вверху), Клавдий Птолемей (справа вверху), Марк Манилий (слева внизу) и Абдуррахман ас-Суфи (справа внизу).

На географической карте изображены Европа, Азия и Африка, которые были картографированы Птолемеем. Но чтобы передать шарообразность Земли, была применена перспективная проекция с точкой зрения, находящейся вне глобуса на расстоянии утроенного диаметра. Методы проектирования интересовали Аюрера и как художника. Аюрер также участвовал в многолетней подготовке издания В. Пиркгеймером «Географии» Птолемея на латинском языке.

${ }^{6}$ См., например, следующие трактаты: «Комментарий на “Пир” Платона» М. Фичино; «Аиалоги о любви» $\Lambda$. Эбрео; «

7 «Соотношение с текстами и соотношение с вещами - одной природы: и здесь, и там люди находят знаки. Однако Бог, дабы развить нашу мудрость, усеял природу лишь теми фигурами, которые нуждаются в истолковании (и именно в этом смысле познание должно быть прорицанием - divinatio)... <..>. Наследие древности, подобно самой природе, - это обширное пространство, взывающее к истолкованию... Аругими словами, Divinatio и Eruditio - это одна и та же герменевтика. Однако разворачивается она на двух различных уровнях, хотя и согласно сходным фигурам: в первом случае она движется от немой отметины к самой вещи (и заставляет говорить природу); во втором случае она движется от неподвижного начертания к ясному слову... $<$... Между метками и словами нет такого различия, как между наблюдением и принятым авторитетом или между истинным и традиционным. Повсюду развертывается одно и то же взаимодействие знака и подобного, и поэтому природа и слово могут перекрещиваться до бесконечности, как бы образуя для умеющего читать великий и единый текст» (Фуко, 1994: 70-71).

8 Он перевел и опубликовал по пожеланию Козимо Медичи «Гимны» и «Аргонавтики» Орфея (1460-1461), Герметический корпус (1461).

9 «И поскольку, управляя телом, она (душа. - И. А.) пребывает также связанной с божественными сущностями, постольку она - госпожа по отношению к телам... <...> Она содержит в себе образы божественных вещей... разумные основания и подобия низших вещей, кото- 
рые определенным образом сама производит. И, будучи средоточием всего (media omnium), она обладает способностями всего... может быть поименована центром природы, средоточием вселенной, цепью мира, ликом всех вещей, а также узами и скрепой мирозданья» (Фичино, 1996: 181-182).

10 «Наблюдая, она (душа. - И. А.), разумеется, познает. Познает же посредством мышления (intelligendo), поскольку признает свою сущность в качестве духовной и свободной от ограничений материи. <...> Зрение, сочетаясь посредством своего духа с духовными образами цветов, видит. <...> Она постигает также божественные вещи, с которыми духовным образом ближе всего связана. Постигает и телесные вещи, к которым она склоняется от природы. <...> ...разумная душа обретается в третьей сущности, удерживает срединную область природы и все вещи связует воедино» (там же: 183-184).

11 «...деятели Возрождения, обычно упоминаемые как представители гуманизма, почти всегда являются последовательными платониками... <..> ...трактовка неоплатонизма приводила тогдашних мыслителей к одушевленной и весьма насыщенной натурфилософии, отличавшейся к тому же использованием весьма четких чувственных ощущений... <..> Это же необходимо обнаруживается и в тогдашних учениях о природе, о ее естественной закономерности и разумности и о необходимости во всем ей подражать. <...> Возрожденческая природа была полна божественных сил, являясь прежде всего предметом самодовлеющего и вполне бескорыстного созерцания, и только в своем крайнем развитии становилась предметом эксперимента или технического преобразования. Отсюда уже указанный выше общеизвестный математический уклон возрожденческого мировоззрения» (Иосев, 1998: 105).

12 «...когда она входит в тело, то целиком присутствует в каждой его части: и не разделяется или не разрывается на части, дабы наличествовать в частях тела, удаленных одна от другой. Ибо силой неделимой (vim individuam), овладевает она телом... <... ...центр, напротив, хотя он и не означен как то, что свойственно какой-то одной окружности, находится в равном отношении ко всему кругу» (Фичино, 1996: 179-180).

13 См. о проблеме платоновского мифа и его интерпретации: Аверинцев, 1979; Гайденко, 1979; Тахо-Годи, 1979.

14 В трактате «Порицание Аристотеля» («Aristotelicae animadversiones», 1543) «Рамус обвинял перипатетиков в том, что логика “непрактична”, запутанна и не соответствует естественному ходу мышления. <... > ...в противоположность логике Аристотеля всем необходимым требованиям отвечала логика Платона, простая и практически применимая, которую Аристотель “испортил”. <..> Причину многих недостатков перипатетической логики Рамус видел в том, что ее приверженцы занимались только анализом слов, оставляя без внимания законы мышления» (Матвиевская, 1981: 90).

\section{СПИСОК АИТЕРАТУРЫ}

Аверинцев, С. С. (1979) Неоплатонизм перед лицом платоновой критики мифопоэтического мышления // Платон и его эпоха : К 2400-летию со дня рождения / отв. ред. Ф. Х. Кессиди. М. : Наука. 318 с. С. 83-97.

Акопян, О. А. (2014а) Платон и Ренессанс: «древняя теология» и примирение с Аристотелем // Платоновский сборник. Т. II / ред. И. А. Протоповова, О. В. Алиева, А. В. Гараджа, А. А. Глухов, А. В. Михайловский, Р. В. Светлов. М. : РГГУ ; СПб. : РХГА. 499 с. С. 320-340.

Акопян, О. А. (2014b) Споры об астрологии в ренессансной мысли второй половины XV начала XVI века : дис. ... канд. ист. наук. М. 445 с.

Гайденко, П. П. (1979) Обоснование научного знания в философии Платона // Платон и его эпоха : К 2400-летию со дня рождения / под ред. Ф. Х. Кессиди. М. : Наука. 318 с. С. 98-143.

Аубова, О. Б. (2009) Становление академической школы в западноевропейской культуре. М. : Памятники исторической мысли. 238 с.

Захаров, Н. В., Гайдин, Б. Н. (2006) Грамматические школы в эпоху Ренессанса: чему учился Шекспир // Высшее образование для XXI века: III Межд. науч. конф., МосГУ, 18-20 октября 
2006 г. : доклады и материалы. Вып. 10 / отв. ред. Н. В. Захаров, Вл. А. Ауков. М. : ИзА-во Моск. гуманит. ун-та. 91 с. С. 49-53.

Захаров, Н. В., Черноземова, Е. Н. (2013) Кристофер Марло: пример реализации концепции нового энциклопедизма [Электронный ресурс] // Информационный гуманитарный портал «Знание. Понимание. Умение». № 1. URL: http://zpu-journal.ru/e-zpu/2013/1/Zakharov-Chernozemova_Marlowe/ (дата обращения: 10.08.2016).

Йейтс, Ф. А. (2000) Ажордано Бруно и герметическая традиция / пер. Г. Аашевского. М. : Новое литературное обозрение. 528 с.

Койре, А. (1985) Очерки истории философской мысли: О влиянии философских концепций на развитие научных теорий / пер. с франц. Я. А. Аяткера ; общ. ред. А. П. Юшкевича. М. : Прогресс. 286 с.

Кудрявцев, О. Ф. (2008) Флорентийская Платоновская академия: очерк истории духовной жизни ренессансной Италии. М. : Наука. 477 с.

Кузанский, Н. (1979) Соч. : в 2 т. М. : Мысль. Т. 1: Перевод. 488 с.

Иисович, И. И. (2015) Скальпель разума и крылья воображения: научные дискурсы в английской культуре раннего Нового времени. М. : Изд. дом Высшей школы экономики. 440 с.

Иосев, А. Ф. (1998) Эстетика Возрождения. Исторический смысл эстетики Возрождения / сост. А. А. Тахо-Годи. М. : Мысль. 750 с.

Матвиевская, Г. П. (1981) Рамус (1515-1572). М. : Наука. 150 с.

Панофски, Э. (2002) Idea: К истории понятия в теориях искусства от античности до классицизма / пер. с нем. Ю. Н. Попова. Изд. 2-е, испр. СПб. : Андрей Наследников. 237 с.

Платон. (2007) Соч. : в 4 т. / под общ. ред. А. Ф. Аосева и В. Ф. Асмуса; пер. с древнегреч. СПб. : Изд-во С.-Петерб. ун-та ; Изд-во Олега Абышко. Т. 3. Ч. 1.752 с.

Рорти, Р. (1997) Философия и зеркало природы : пер. с англ. / науч. ред. В. В. Целищев. Новосибирск : Иза-во Новосиб. ун-та. XXII, 298 с.

Смит, Р. (2008) История гуманитарных наук / пер. с англ. под науч. ред. А. М. Носова. 2-е изд. М. : Изд. Аом ГУ ВШЭ. 392 с.

Софронова, $\Lambda$. В. (2006) К проблеме философских истоков «христианского гуманизма»: корреспонденция Фичино и Колета // Вестник Нижегородского университета им. Н. И. Аобачевского. Сер.: Социальные науки. № 1. С. 599-606.

Софронова, А. В. (2009) Ажон Колет: опыт реставрации образа христианского мыслителя ренессансной эпохи. Н. Новгород : Изд-во НГПУ. 447 с.

Тахо-Годи, А. А. (1979) Миф у Платона как действительное и воображаемое // Платон и его эпоха : К 2400-летию со дня рождения / под ред. Ф. Х. Кессиди. М. : Наука. 318 с. С. 58-82.

Фичино, М. (1981) Комментарий на «Пир» Платона, о любви // Эстетика Ренессанса : Антология : в 2 т. / сост. и науч. ред. В. П. Шестаков. М. : Искусство. Т. 1. 495 с. С. 144-235.

Фичино, М. (1996) Платоновское богословие о бессмертии душ // Чаша Гермеса: Гуманистическая мысль эпохи Возрождения и герметическая традиция / сост. О. Ф. Кудрявцев. М. : Юристъ. 336 с. С. 176-211.

Фуко, М. (1994) Слова и вещи. Археология гуманитарных наук / пер. с фр. В. П. Визгина, Н. С. Автономовой ; вст. статья Н. С. Автономовой. СПб. : А-cad. 405 с.

Cassirer, E. (1953) The Platonic Renaissance in England. Edinburgh : Nelson. vii, 207 p.

Castillo, D. R. (2010) Baroque horrors: Roots of the fantastic in the age of curiosities. Ann Arbor, MI : The University of Michigan Press. xv, $177 \mathrm{p}$.

Chadwick, H. (1984) Early Christian thought and the classical tradition: Studies in Justin, Clement, and Origen. 2nd edn. Oxford : Clarendon Press ; N. Y. : Oxford University Press. 174 p.

Chen-Morris, R. (2013) “The quality of nothing”: Shakespearean mirrors and Kepler's visual economy of science // Science in the age of Baroque / ed. by O. Gal, R. Chen-Morris. Dordrecht ; N. Y. : Springer. vi, 313 p. (International archives of the history of ideas, vol. 208). P. 99-118.

Clark, S. (2007) Vanities of the eye: Vision in Early Modern European culture. Oxford : Oxford University Press. xi, 415 p. 
Gal, O. (2013) From divine order to human approximation: Mathematics in Baroque science // Science in the age of Baroque / ed. by O. Gal, R. Chen-Morris. Dordrecht ; N. Y. : Springer. vi, 313 p. (International archives of the history of ideas, vol. 208). P. 77-96.

Gilman, E. B. (1978) The curious perspective: Literary and pictorial wit in the seventeenth century. New Haven, CT ; L. : Yale University Press. xii, 267 p.

Jayne, S. R. (1963) John Colet and Marsilio Ficino. Oxford : Oxford University Press. 172 p.

Jayne, S. R. (1995) Plato in Renaissance England. Dordrecht ; Boston ; L. : Kluwer Academic Publishers. xx, 197 p. (International archives of the history of ideas, vol. 141).

John Dee: Interdisciplinary studies in English Renaissance thought (2006) / ed. by S. Clucas. Dordrecht : Springer. xvii, 366 p. (International archives of the history of ideas, vol. 193).

Kearney, H. F. (1970) Scholars and gentlemen: Universities and society in pre-industrial Britain, 1500-1700. L. : Faber \& Faber. 214 p.

Klibansky, R. (1939) The continuity of the Platonic tradition during the Middle Ages: Outlines of a Corpus platonicum medii aevi. L. : Warburg Institute (reprint: N. Y., 1982). 3 pr. leaves, ix, 58 p.

Order of Queen Elizabeth prohibiting the residence of women in colleges (1853) // Correspondence of Matthew Parker, D.D. Archbishop of Canterbury: comprising letters written by and to him, from A. D. 1535, to his death, A.D. 1575 / ed. by J. Bruce, T. Perowne. Cambridge : Printed at the University Press. xxiv, 510 p. P. 146-147.

Platonism at the origins of modernity: Studies on Platonism and Early Modern philosophy (2008) / ed. by D. Hedley, S. Hutton. Dordrecht : Springer. ix, 285 p. (International archives of the history of ideas, vol. 196).

Schmitt, C. B. (1967) Gianfrancesco Pico Della Mirandola (1469-1533) and his critique of Aristotle. The Hague : M. Nijhoff. xiv, 252 p. (International archives of the history of ideas, vol. 23).

The Platonic tradition in the Middle Ages: A doxographic approach (2002) / ed. by S. Gersh, M. J. F. M. Hoenen. Berlin ; N. Y. : Walter de Gruyter. viii, 466 p.

Аата поступления: 12.08.2016 г.

\section{SCIENCE, NEO-PLATONISM AND LIBERAL ARTS IN THE CULTURE \\ OF ENGLAND IN THE EARLY MODERN PERIOD \\ I. I. LISOVICH \\ (MOSCOW UNIVERSITY FOR THE HUMANITIES)}

The article examines the influence of neo-Platonic discourse on scientific knowledge and liberal arts in England and Europe in the Early Modern period. Aspiring to overwhelm the impact of scholasticism and Aristotle, humanists turned to Plato's philosophy. The publication of the complete works of Plato by M. Ficino preceded the beginning of the scientific revolution and analytical interest in the details of the physical world. Plato's philosophy reached England through the correspondence between M. Ficino and J. Colet. In the mid-16th century, Plato's texts, along with those by Aristotle, became the backbone of English university education. From the Platonic Academy came the idea of the open scientific and educational space for Europeans and the English. This allowed advancing new knowledge fast. Gresham College and the Royal Society of London were founded in England; public lectures were being delivered.

The concept of the visual, which can be traced to Plato's doctrine, became the basis for the observation sciences and the system of argumentation and providing evidence in the 'new philosophy'. Appealing to Plato's understanding of geometry, harmony and man made it possible to assign the status of liberal arts to pictorial art and anatomy which had been previously thought to belong to the field of 'techne' - crafts requiring physical labour. Ideas of Plato, neo-Platonists and representatives of the 'new philosophy' can be found in the poetical works by such authors as Ph. Sydney, C. Marlowe, W. Shakespeare and B. Jonson. The anatomical theories of A. Vesalius and W. Harvey, observational astronomy of T. Brahe, J. Kepler, G. Galilei and theoretical and methodological constructions of G. Bruno, F. Bacon, R. Descartes and I. Newton - all of these made use of Plato's notions of 
harmony, proportion and measure. This gave an opportunity to describe and measure observable objects accurately.

Keywords: culture of England; early Modern period; scientific knowledge; Plato; Neo-Platonism; Aristotle; the visual; evidence; liberal arts; new philosophy

\section{REFERENCES}

Averintsev, P. S. (1979) Neoplatonizm pered litsom platonovoi kritiki mifopoeticheskogo myshleniia. In: Platon i ego epokba : K 2400-letiiu so dnia rozbdeniia / ed. by F. Kh. Kessidi. Moscow, Nauka Publ. 318 p. Pp. 83-97. (In Russ.)

Akopian, O. L. (2014a) Platon i Renessans: «drevniaia teologiia» i primirenie s Aristotelem. In: Platonovskii sbornik. Vol. II / ed. by I. A. Protopovova, O. V. Alieva, A. V. Garadzha, A. A. Glukhov, A. V. Mikhailovskii and R. V. Svetlov. Moscow, Russian State University for the Humanities Publ. ; St. Petersburg, Russian Christian Academy for the Humanities Publ. 499 p. Pp. 320-340. (In Russ.)

Akopian, O. L. (2014b) Spory ob astrologii v renessansnoi mysli vtoroi poloviny XV - nachala XVI veka: Diss. ... Candidate of History. Moscow. 445 p. (In Russ.)

Gaidenko, P. P. (1979) Obosnovanie nauchnogo znaniia v filosofii Platona. In: Platon i ego epokba : K 2400-letiiu so dnia rozbdeniia / ed. by F. Kh. Kessidi. Moscow, Nauka Publ. 318 p. Pp. 98-143. (In Russ.)

Dubova, O. B. (2009) Stanovlenie akademicheskoi shkoly v zapadnoevropeiskoi kul'ture. Moscow, Pamiatniki istoricheskoi mysli Publ. 238 p. (In Russ.)

Zakharov, N. V. and Gaydin, B. N. (2006) Grammaticheskie shkoly v epokhu Renessansa: chemu uchilsia Shekspir. In: Vysshee obrazovanie dlia XXI veka: III Mezbdunarodnaia nauchnaia konferentsiia, MosGU, 18-20 oktiabria 2006 g. : Reports and proceedings. Issue 10 / ed. by N. V. Zakharov end Vl. A. Lukov. Moscow, Moscow University for the Humanities Publ. 91 p. Pp. 49-53. (In Russ.)

Zakharov, N. V. and Chernozemova, E. N. (2013) Kristofer Marlo: primer realizatsii kontseptsii novogo entsiklopedizma. Informatsionnyi gumanitarnyi portal "Znanie. Ponimanie. Umenie", no. 1. [online] Available at: http://zpu-journal.ru/e-zpu/2013/1/Zakharov-Chernozemova_Marlowe/ (accessed 10.08.2016). (In Russ.)

Yates, F. A. (2000) Dzhordano Bruno $i$ germeticheskaia traditsiia / transl. by G. Dashevskii. Moscow, Novoe literaturnoe obozrenie Publ. 528 p. (In Russ.)

Koyré, A. (1985) Ocherki istorii filosofskoi mysli: O vliianii filosofskikb kontseptsii na razvitie nauchnykb teorii / transl. by Ya. A. Liatker; ed. by A. P. Yushkevich. Moscow, Progress Publ. 286 p. (In Russ.)

Kudriavtsev, O. F. (2008) Florentiiskaia Platonovskaia akademiia: ocherk istorii dukbovnoi zhizni renessansnoi Italii. Moscow, Nauka Publ. 477, [1] p. (In Russ.)

Nicholas of Cusa. (1979) Sochineniia [Works] : in 2 vols. Moscow, Mysl' Publ. Vol. 1: Perevod. 488 p. (In Russ.)

Lisovich, I. I. (2015) Skal'pel' razuma i kryl'ia voobrazbeniia: naucbnye diskursy $v$ angliiskoi kul'ture rannego Novogo vremeni. Moscow, Publ. House of the Higher School of Economics. 440 p. (In Russ.)

Losev, A. F. (1998) Estetika Vozrozhdeniia. Istoricheskii smysl estetiki Vozrozhdeniia/ comp. by A. A. Takho-Godi. Moscow, Mysl' Publ. 750 p. (In Russ.)

Matvievskaia, G. P. (1981) Ramus (1515-1572). Moscow, Nauka Publ. 150 p. (In Russ.)

Panofsky, E. (2002) Idea: K istorii poniatiia v teoriiakb iskusstva ot antichnosti do klassitsizma / transl. by Yu. N. Popov. 2nd edn., revised. St. Petersburg, Andrei Naslednikov Publ. 237 p. (In Russ.)

Plato. (2007) Sochineniia [Works] : in 4 vols. / ed. by A. F. Losev and V. F. Asmus ; transl. from Ancient Greek. St. Petersburg, St. Petersburg University Publ.; Oleg Abyshko's Publ. Vol. 3. Pt. 1. 752 p. (In Russ.)

Rorty, R. (1997) Filosofiia i zerkalo prirody : transl. from English / ed. by V. V. Tselishchev. Novosibirsk, Novosibirsk University Publ. XXII, 298 p. (In Russ.) 
Smith, R. (2008) Istoriia gumanitarnykb nauk / transl. from English ed. by D. M. Nosov. 2nd edn. Moscow, Publ. House of the Higher School of Economics. 392 p. (In Russ.)

Sofronova, L. V. (2006) K probleme filosofskikh istokov «khristianskogo gumanizma»: korrespondentsiia Fichino i Koleta. Vestnik Nizhegorodskogo universiteta im. N. I. Lobachevskogo. Seriia: Sotsial' nye nauki, no. 1, pp. 599-606. (In Russ.)

Sofronova, L. V. (2009) Dzhon Kolet: opyt restavratsii obraza kbristianskogo myslitelia renessans-noi epokbi. Nizhny Novgorod, Nizhny Novgorod State Pedagogical University Publ. 447 p. (In Russ.)

Takho-Godi, A. A. (1979) Mif u Platona kak deistvitel'noe i voobrazhaemoe. In: Platon i ego epokba: K 2400-letiiu so dnia rozbdeniia / ed. by F. Kh. Kessidi. Moscow, Nauka Publ. 318 p. Pp. 58-82. (In Russ.)

Ficino, M. (1981) Kommentarii na «Pir» Platona, o liubvi. In: Estetika Renessansa: An anthology : in 2 vols. / comp. and ed. by V. P. Shestakov. Moscow, Iskusstvo Publ. Vol. 1. 495 p. Pp. 144-235. (In Russ.)

Ficino, M. (1996) Platonovskoe bogoslovie o bessmertii dush. In: Chasha Germesa: Gumanisticheskaia mysl' epokbi Vozrozbdeniia i germeticheskaia traditsiia / comp. by O. F. Kudriavtsev. Moscow, Iurist» Publ. 336 p. Pp. 176-211. (In Russ.)

Foucault, M. (1994) Slova i vesbchi. Arkbeologiia gumanitarnykb nauk/ transl. by V. P. Vizgin and N. S. Avtonomova ; introduction by N. S. Avtonomova. St. Petersburg, A-cad Publ. 405 p. (In Russ.)

Cassirer, E. (1953) The Platonic Renaissance in England. Edinburgh, Nelson. vii, 207 p.

Castillo, D. R. (2010) Baroque borrors: Roots of the fantastic in the age of curiosities. Ann Arbor, MI, The University of Michigan Press. xv, 177 p.

Chadwick, H. (1984) Early Christian thought and the classical tradition: Studies in Justin, Clement, and Origen. 2nd edn. Oxford, Clarendon Press ; New York, Oxford University Press. $174 \mathrm{p}$.

Chen-Morris, R. (2013) “The quality of nothing”: Shakespearean mirrors and Kepler's visual economy of science. In: Science in the age of Baroque / ed. by O. Gal and R. Chen-Morris. Dordrecht ; New York, Springer. vi, 313 p. (International archives of the history of ideas, vol. 208). Pp. 99-118.

Clark, S. (2007) Vanities of the eye: Vision in Early Modern European culture. Oxford, Oxford University Press. xi, 415 p.

Gal, O. (2013) From divine order to human approximation: Mathematics in Baroque science. In: Science in the age of Baroque / ed. by O. Gal and R. Chen-Morris. Dordrecht ; New York, Springer. vi, 313 p. (International archives of the history of ideas, vol. 208). Pp. 77-96.

Gilman, E. B. (1978) The curious perspective: Literary and pictorial wit in the seventeenth century. New Haven, CT ; London, Yale University Press. xii, 267 p.

Jayne, S. R. (1963) Jobn Colet and Marsilio Ficino. Oxford, Oxford University Press. 172 p.

Jayne, S. R. (1995) Plato in Renaissance England. Dordrecht ; Boston ; London, Kluwer Academic Publishers. xx, 197 p. (International archives of the history of ideas, vol. 141).

Jobn Dee: Interdisciplinary studies in English Renaissance thought (2006) / ed. by S. Clucas. Dordrecht, Springer. xvii, 366 p. (International archives of the history of ideas, vol. 193).

Kearney, H. F. (1970) Scholars and gentlemen: Universities and society in pre-industrial Britain, 1500-1700. London, Faber \& Faber. 214 p.

Klibansky, R. (1939) The continuity of the Platonic tradition during the Middle Ages: Outlines of a Corpus platonicum medii aevi. London, Warburg Institute (reprint: New York, 1982). 3 pr. leaves, ix, $58 \mathrm{p}$.

Order of Queen Elizabeth prohibiting the residence of women in colleges. (1853) In: Correspondence of Matthew Parker, D.D. Archbishop of Canterbury: comprising letters written by and to bim, from A.D. 1535, to bis death, A. D. 1575 / ed. by J. Bruce and T. Perowne. Cambridge, Printed at the University Press. xxiv, 510 p. Pp. 146-147. 
Platonism at the origins of modernity: Studies on Platonism and Early Modern philosopby (2008) / ed. by D. Hedley and S. Hutton. Dordrecht, Springer. ix, 285 p. (International archives of the history of ideas, vol. 196).

Schmitt, C. B. (1967) Gianfrancesco Pico Della Mirandola (1469-1533) and his critique of Aristotle. The Hague, M. Nijhoff. xiv, 252 p. (International archives of the history of ideas, vol. 23).

The Platonic tradition in the Middle Ages: A doxographic approach (2002) / ed. by S. Gersh and M. J. F. M. Hoenen. Berlin ; New York, Walter de Gruyter. viii, 466 p.

Submission date: 12.08.2016.

Аисович Инна Ивановна - доктор культурологии, кандидат филологических наук, профессор кафедры философии, культурологии и политологии Московского гуманитарного университета. Адрес: 111395, Россия, г. Москва, ул. Юности, д. 5. Тел.: +7 (499) 374-55- 11. Эл. адрес: mag-inna@yandex.ru

Lisovich Inna Ivanovna, Doctor of Culturology, Candidate of Philology, Professor, Department of Philosophy, Culturology and Politology, Moscow University for the Humanities. Postal address: 5 Yunosti St., 111395 Moscow, Russian Federation. Tel.: +7 (499) 374-55-11. E-mail: mag-inna@yandex.ru 